\title{
Os retratos, a terra e o que há acima e abaixo dela
}

Los retratos, la tierra y lo que está arriba y debajo de ella

Monique Burigo Marin ${ }^{1}$

${ }^{1}$ Mestranda em Artes Visuais, na linha de Teoria e História das Artes Visuais, pela UDESC, com bolsa CAPES, orientada por Sandra Makowiecky. Graduada em Comunicação Social, com ênfase em Publicidade e Propaganda, pela UNIVALI. Currículo Lattes: http://lattes.cnpq.br/5294996851445225 Contato: moniqueburigomarin@gmail.com 


\section{Resumo}

Através de retratos e autorretratos de períodos diversos, verifica-se por meio de recurso didático comparativo a permanência de temas como o tempo, os ciclos, os diferentes tipos de morte e vida e a relação com a natureza expressos em pintura e fotografias de artistas brasileiros e estrangeiros, como os já consagrados John Everett Millais e Francesca Woodman, mas também abordando a produção de artistas fotógrafas da região Sul do Brasil: Danny Bittencourt, Sarah Uriarte e Lilian Barbon, que se encontram em diferentes momentos de suas carreiras. Há um fio condutor entre as obras, que se relacionam, embora nunca tenham se encontrado antes. Acredita-se que existe forte ligação entre aquilo que se assemelha e, por este motivo, a escolha das imagens não se dá por acaso e julga-se necessário colocá-las em diálogo.

\section{Palavras-chave}

fotografia de autorretrato; retrato; autorretrato de mulheres

\section{Resumen}

A través de retratos y autorretratos de diferentes períodos, es posible verificar, a través de un recurso didáctico comparativo, la permanencia de temas como el tiempo, los ciclos, los diferentes tipos de muerte y vida y la relación con la naturaleza expresada en la pintura y las fotografías de artistas brasileños y extranjeros, como los conocidos John Everett Millais y Francesca Woodman, pero también en la producción de artistas fotógrafas del sur de Brasil: Danny Bittencourt, Sarah Uriarte y Lilian Barbon, que se encuentran en diferentes momentos de sus carreras. Hay un hilo conductor entre las obras, que están relacionadas, aunque nunca antes se habían encontrado. Se cree que existe una fuerte conexión entre lo que es similar y, por esta razón, la elección de las imágenes no ocurre por casualidad y se considera necesario ponerlas en diálogo.

\section{Palabras clave}

fotografía de autorretrato; retrato; autorretrato de mujeres

ISSN: 2447-1267 
Uma imagem nunca está só; ela se apresenta junto com outras, invocadas por associação pela memória de quem observa. Olhar imagens realizadas em diferentes períodos históricos e estabelecer comparações entre elas, é um excelente recurso didático no ensino das artes. Diz Coli (2010):

Os historiadores da arte sabem, no entanto, que existe uma ligação forte entre coisas que se assemelham. A história da arte moderna afirmouse com a fotografia, ou seja, com algo que reproduz um original. São as fotos de quadros, de estátuas, de edifícios, que permitem aos historiadores os estudos comparativos. Eles trabalham com imagens de imagens. Os grandes centros internacionais de estudos em história das artes possuem grandes mesas. Grandes mesas são necessárias e indispensáveis: sobre elas podem-se dispor várias fotografias e comparar. Comparar é uma forma de compreensão silenciosa da relação entre as imagens. [...] Os historiadores da arte costumam dizer que é preciso treinar o olho. Isto significa incorporar um saber, sempre silencioso, sempre intuitivo, capaz de captar o que há de comum entre as formas.

Foi isso o que aconteceu ao encontrar com a pintura The Vale of Rest, ou $O$ Vale do Descanso (Figura 1), feita por John Everett Millais em 1858 - finalizada em 1859 -, integrante da exposição Preraffaelliti: Amore e Desiderio (Pré-rafaelitas: amor e desejo), no Palazzo Reale de Milão, em 2019. Pensei em comparações e estabeleci algumas relações que deram origem ao texto.

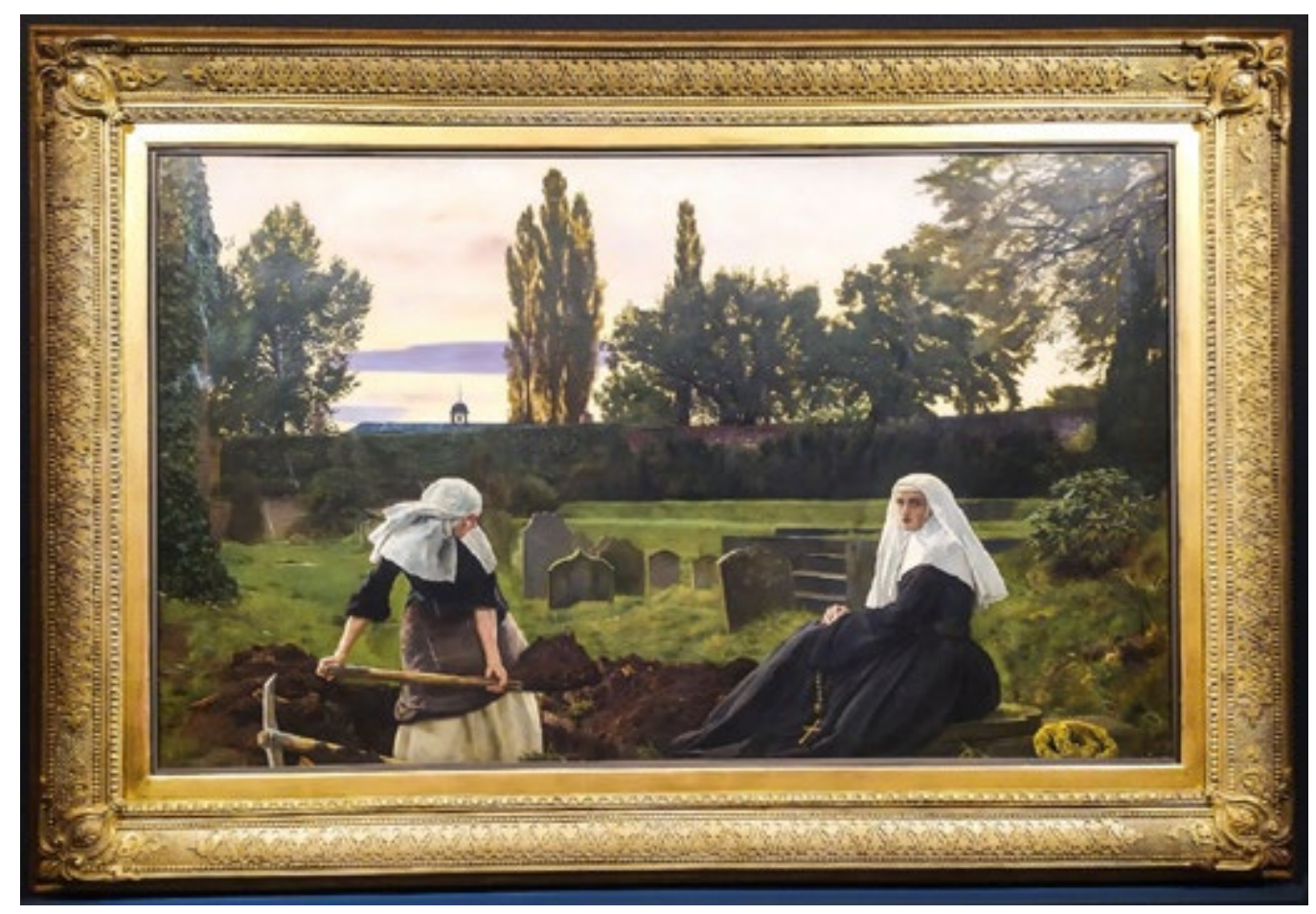

Fig. 1. The Vale of Rest, John Everett Millais, 1858-1859, Óleo sobre tela, 1029 x 1727 mm. Fonte: Fotografia feita pela autora, no Palazzo Reale.

Olhar para este quadro, e dar tempo a ele, foi como sentir a terra caindo sobre o rosto, com seu cheiro úmido e seu gosto denso. Para Didi-Huberman (2018), é preciso 
fundir-se à imagem para atingir sua profundidade, pois imagens não são fáceis de compreender e nem se revelam de imediato. É necessário implicar-se e fazer disso uma experiência.

Assim, as árvores não balançam, o verde perde a cor, as lápides estão vazias. A forma como o buraco se apresenta, na pintura, dá a sensação de que o observador está dentro dele. A quietude e imobilidade parece ser quebrada apenas pelo som da pá entrando no solo; ou também pelo arfar da freira que cava o buraco, parecendo muito concentrada e forte, com grandes e pesadas ferramentas. Essa representação era bastante moderna para a época de criação da obra, quando não era comum que mulheres fossem pintadas com características enérgicas e fortes, por isso foi muito criticada, embora o próprio Millais tenha dito que esta era sua obra favorita (FOWLE, 2019).

A força no olhar da freira que encara o espectador também é bastante notável, e parece ao mesmo tempo confrontar e convidar ao repouso que, com esperança, aguarda quem deitar na cova aberta. Sua postura parece indicar que aceitou a morte, ainda que o rosário em suas mãos lembre a fé cristã e a vida eterna da alma, seu olhar é aterrorizante como a própria morte pode ser. Esta obra faz pensar na imortalidade e na fugacidade da vida. No céu, o pôr do sol lembra que a morte é um fenômeno natural: como as árvores, deixaremos de balançar. Como o verde, perderemos a cor. Como as lápides, nosso corpo estará vazio. Chegará a nossa vez.

O tempo dedicado à imagem traz à tona um pensamento conflitante com a interpretação anterior: talvez a cova não esteja sendo cavada para enterrar um corpo, mas sim para exumar um que já está debaixo da terra, como que para trazer à superfície a realidade da morte. Até mesmo para investigar sua causa, analisar seu aspecto e encarar sua face: que pode ser a mesma de todos nós, como se a freira, ao nos encarar, já soubesse o que está escondido.

O Vale do Descanso (Figura 1) fez com que recordasse de outra obra, que viria a nascer muitos anos depois no Brasil, pelas mãos de uma mulher: Danny Bittencourt. "Nada permite melhor entender uma obra do que outra" (COLI, 2010). Esta obra (Figura 2), na verdade, é plural e talvez não possa ser descrita no singular. Como parte da série fotográfica intitulada 200 dias para dentro, Danny enterrou um de seus autorretratos em uma forma de bolo, que ficou em seu jardim durante três meses, sofrendo as ações do tempo: a proposta da experiência era investigar o que iria sobrar, o que viraria aquela imagem depois de todo o trauma, o que eu mesma iria me tornar. (BITTENCOURT, 2018).

Toda a cerimônia fúnebre evocada em O Vale do Descanso (Figura 1), retorna nos atos da artista brasileira que não só enterrou sua própria imagem, como a exumou posteriormente, refotografando seu autorretrato, agora marcado pelo tempo e a natureza. Essas ações também remetem aos rituais narrados por Didi-Hubermann em seu texto intitulado $O$ rosto e a terra: onde começa o retrato, onde se ausenta o rosto.

Conta que na Nova Caledônia, por exemplo, após a morte devia-se esvaziar todos os lugares onde esta pessoa vivera, ateando fogo em sua casa e em seus pertences, devastando suas plantações, entre outros atos aparentemente violentos, 
mas que constituíam sua forma de demonstrar sofrimento pela perda. E assim começa um ritual que envolve o corpo, e principalmente o rosto, do defunto: "acompanhando o corpo para o lugar de sua sepultura, delegam alguém para abrir a marcha e encher sua boca com restos de plantas; os cuidadores enchem também suas narinas de ervas odoríferas." (ARTSTUDIO N²1, 1991). A cabeça recebe especial atenção. Após ter o corpo posicionado de cócoras - antes que este tenha tempo de se enrijecer - e amarrado para que não possa voltar a caminhar entre os vivos, um buraco circular é cavado em meio à natureza, onde é colocado em posição vertical, com a cabeça para fora da terra e coberta por plantas. A cabeça era sustentada por uma madeira imputrescível e permanecia conservada após o apodrecimento do cadáver, então era removida e esculpida e depois devolvida à família, para que pudesse continuar cuidando de seus familiares mesmo depois de sua morte.

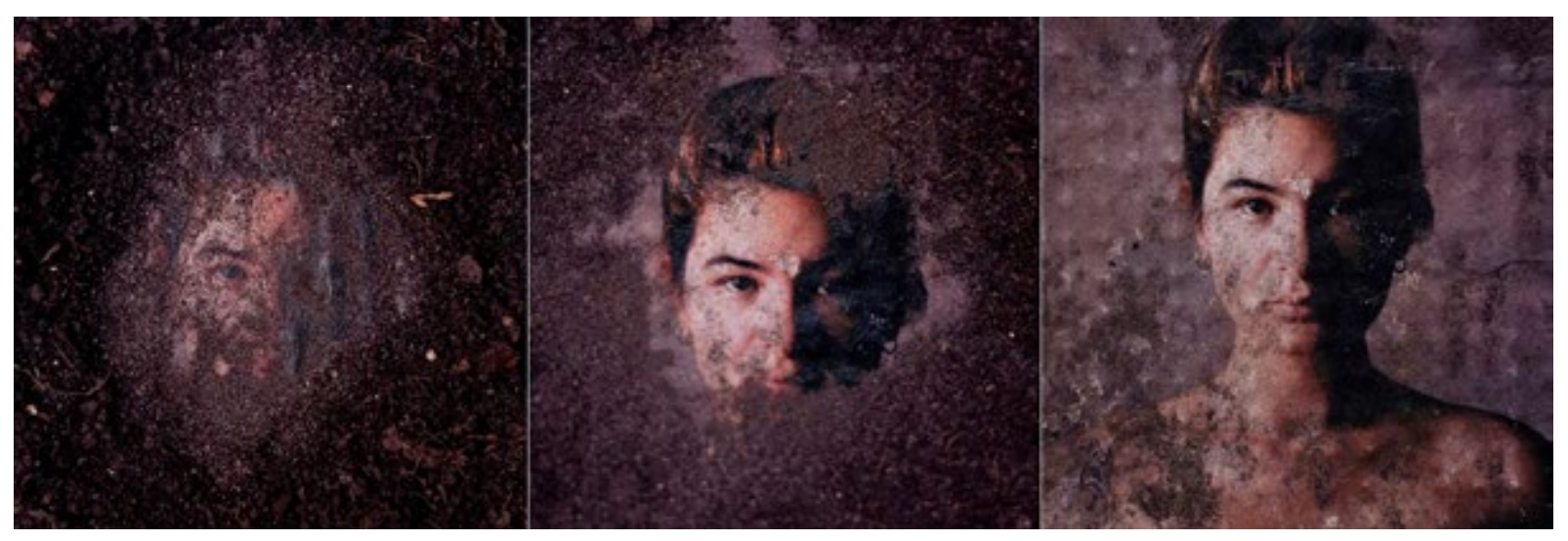

Fig. 2. Sem título, Danny Bittencourt, 2018. Fotografia híbrida. Fonte: https://dannybittencourt.com/ projects/200-dias-para-dentro/

Para Agamben (2012), a contemporaneidade é uma revenant uma luz é projetada sobre o passado e, assim, ele volta. Dessa maneira, obras do passado podem ser melhor compreendidas com o olhar do presente, que pode encontrar nelas um sentido. Estas imagens produzidas em 2018, por si só, são efêmeras como a vida. Existem somente como memória fotografada, e não mais como objeto tátil. Mesmo assim, é possível sentir a terra na palma das mãos, como se, ao observar as imagens, participasse do processo e quisesse remover a terra que sufoca a figura humana debaixo dela.

A terra foi saindo com dificuldade, pois já estava impregnada no papel, fui notando que várias partes da imagem haviam descascado, cicatrizes. Aceitei que elas precisavam mesmo estar ali, afinal eram parte dessa história, mas continuei a raspar a terra, respeitando os desgastes, mas ainda procurando qualquer tipo de brilho no olho que me encarava, enterrado.(BITTENCOURT, 2018)

Mesmo que o processo de feitura fosse deixado de lado, por desconhecimento ou intenção, o tríptico apresenta em si mesmo este processo, de acordo com a 
ordenação das imagens. $\bigcirc$ autorretrato se modifica gradativamente, e nele estão implícitos o tempo e a ação. A extração de sentidos pode ser múltipla ao se embaralhar a ordem, e ao apresentar as imagens sem título e ordenação, a artista deixa isso por conta do observador, que pode ordenar e interpretar como quiser.

Ordenadas como se encontram aqui, a terra e a sujeira tomam conta primeiro, e apenas um olho se mostra. Depois, a imagem vai ficando mais limpa e nítida e já é possível distinguir um rosto. Por último, o busto de uma mulher encara o espectador, como a freira em $O$ Vale do Descanso (Figura 1), talvez esteja a nos lembrar - e a lembrar a si mesma - de que o tempo engole. Mas, como a terra engole sementes, algo ainda poderá brotar.

Uma imagem leva à outra e, assim, surge a obra Enfim (Figura 3), da artista catarinense Sarah Uriarte. Outro tríptico em que a sequência, quando embaralhada, pode mudar o rumo das interpretações. Esta obra, de 2019, também é um autorretrato.

Ao traçar uma linha vertical imaginária no meio da imagem, a simetria logo se faz visível. Para cada lado uma porta, um vaso com planta e uma figura feminina. Repetem-se proeminentemente formas retas e angulosas como o retângulo, que por sua vez cria triângulos nas bordas dos degraus. A simetria remete aos organismos vivos e às formas da natureza, assim como os vasos circulares com plantas, enquanto as formas retas e angulosas são como uma interferência no ciclo da vida, que pode ser interrompido a qualquer momento, por fatalidade ou intenção.

Conforme apresentadas aqui, e de acordo com a ordem em que aparecem no portfólio da artista, na primeira fotografia Sarah parece prestes a entrar pela porta à esquerda, saindo pela porta à direita na última imagem. Ocorre um hiato entre uma ação e outra e o cenário fica vazio. Há um início, um meio e um fim. O próprio título remete à passagem do tempo e ao que finda, mas também pode funcionar como uma interjeição: enfim, já que não há outro jeito. Tudo finda, queiramos ou não. A imagem do meio, no entanto, instiga a curiosidade sobre o que ocorre entre o início e o fim e nela se perde a noção de tempo, faz pensar no que acontece atrás das portas fechadas e, por um instante, se faz infinita.

As portas, no entanto, nunca estão de fato abertas, ocorre apenas a impressão de que estiveram ou estarão em algum momento. Uma espécie de ilusão criada pela posição em que Sarah se encontra nas imagens. $O$ tempo se encolhe ao analisar os detalhes, como a luz que não indica passagem de tempo e as plantas que permanecem vivas e plantadas em seus vasos. A personagem entra e sai parecendo a mesma. As roupas são iguais em ambas as fotografias e sua aparência continua jovem. Essa é uma verdade possível, no entanto, abre precedente para pensar que ninguém entra e sai igual de uma experiência, ainda que possa parecer que sim.

O tempo parece se misturar na própria imagem. Sarah está no presente, com seu cabelo e suas roupas, mas o local onde se encontra remete a um tempo em algum lugar no passado. As paredes, portas, escadas e vasos parecem desgastados e corroídos pelo tempo que por ali passou lentamente, mas não sem deixar suas marcas ou sem reforçar seu poder destrutivo. Essas marcas configuram-se como ruínas e como cicatrizes, são parte de um corpo ou de um cadáver - separando-os há apenas o tempo. 
O olhar de Sarah ignora o espectador, ao contrário dos olhares lançados pelas mulheres nas obras de John Everett Millais (Figura 1) e Danny Bittencourt (Figura 2). Seu olhar parece concentrado na ação e em si mesmo, assim como acontece na fotografia de Francesca Woodman (Figura 4). Neste autorretrato, Francesca encontrase nua dentro da água, em mimetismo com as raízes de uma árvore, seu olhar está focado na ação e embora a fotografia aparentemente congele seu movimento, incorporando seu corpo à natureza, é possível enxergar as perturbações feitas por ela na água.
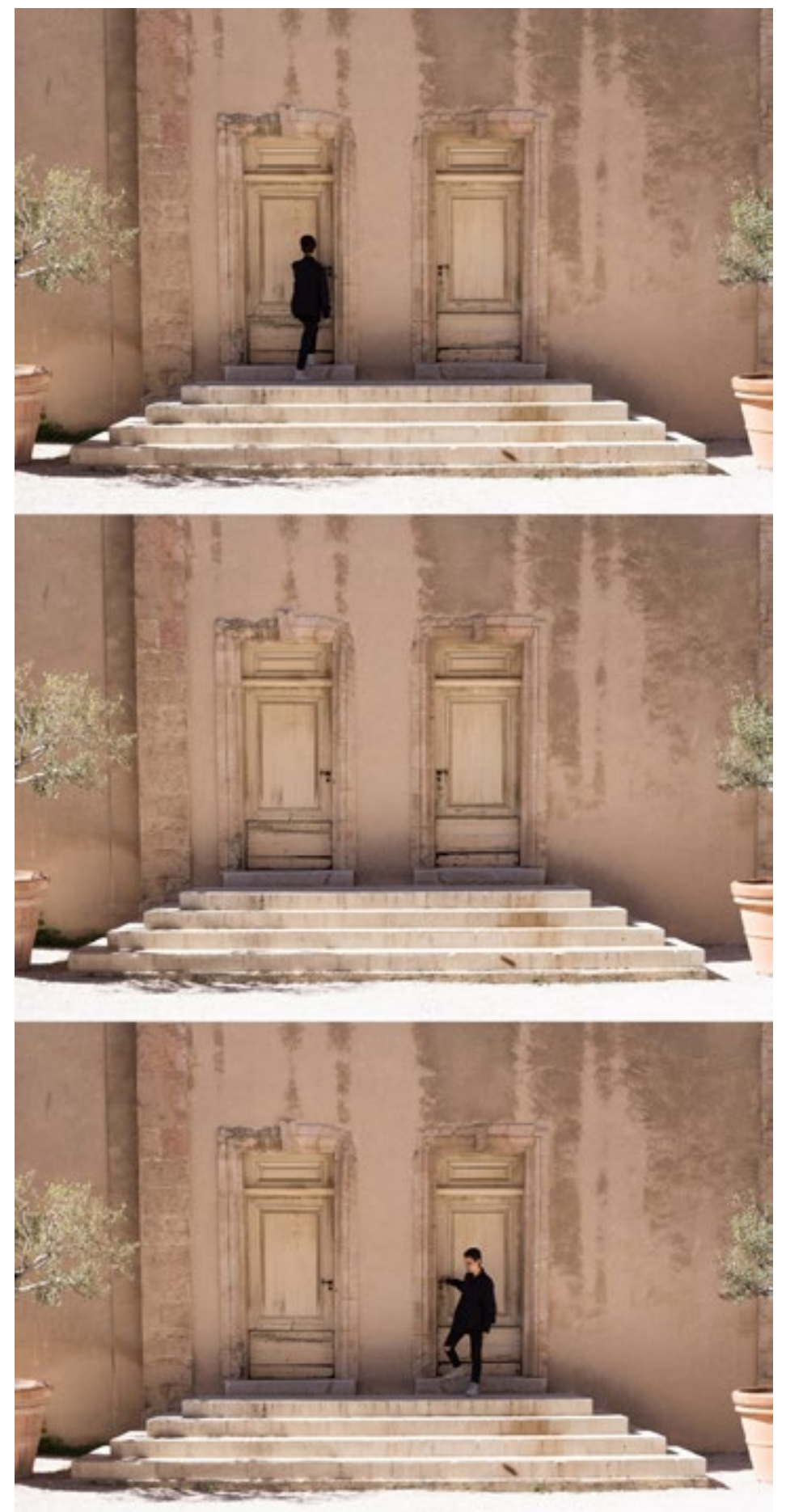

Fig. 3. Enfim, Sarah Uriarte, 2019. Fotografia. Fonte: https://sarahuriarte.com/enfim 


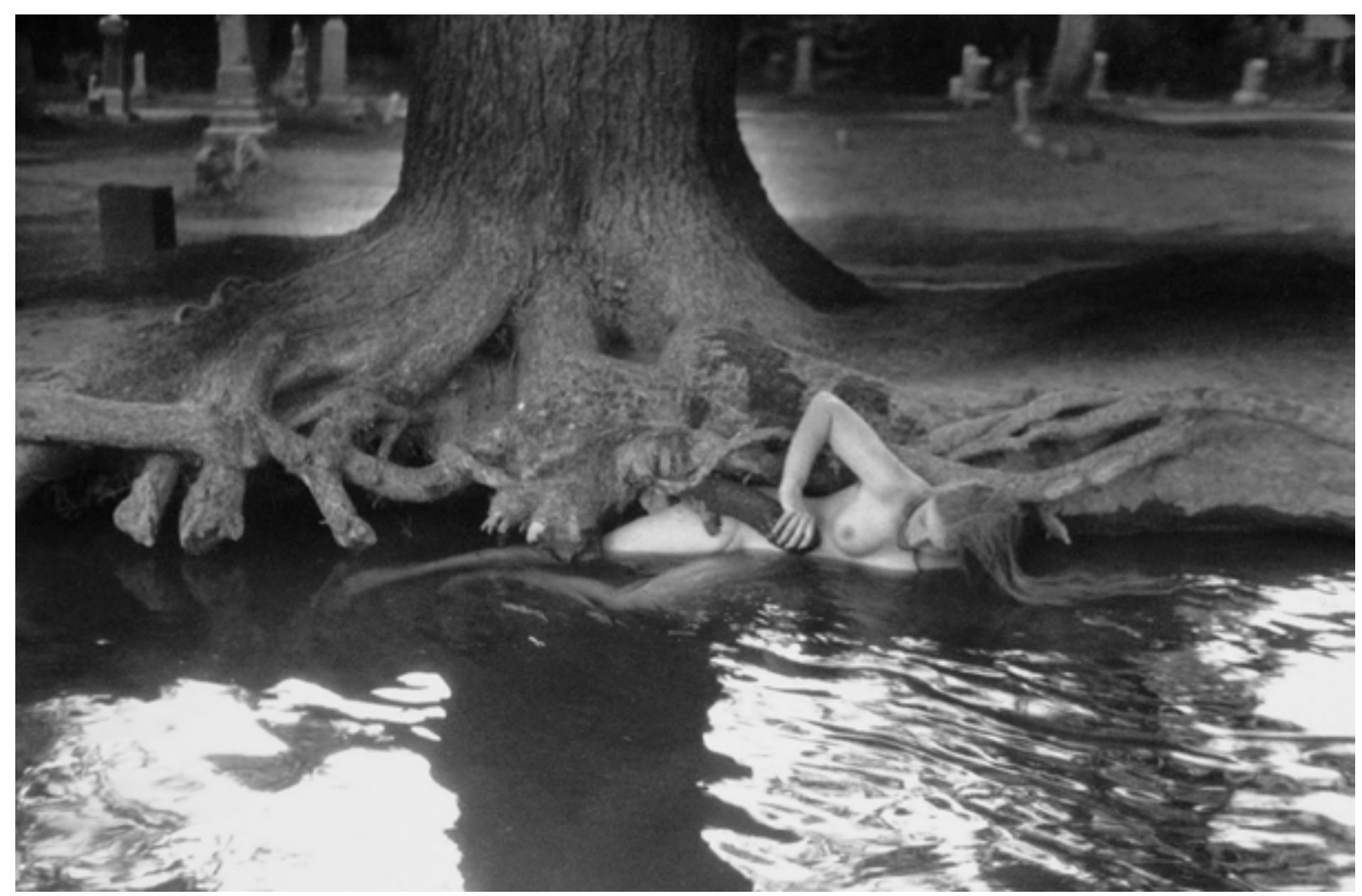

Fig. 4. Sem título, Francesca Woodman, 1976. Fotografia. Fonte: https://tabutmag.com/francescawoodman/

Os contrastes presentes na fotografia sinalizam para contrastes como vida e morte e céu e inferno. Há um fraco reflexo na água, que brilha com intensidade, onde é possível imaginar o céu. Um céu que se projeta na água e também abaixo da linha da terra. Os elementos se mesclam e os lugares se confundem. Ar, água, terra e uma luz como o fogo brando de uma vela acesa, que sobreviveu à força do vento, ao toque da água e ao peso da terra. Francesca é ao mesmo tempo uma mulher, um fantasma e uma parte da natureza.

A leitura desta fotografia conduz a outras duas: o autorretrato Soul of the Blasted Pine (Alma do Pinheiro Maldito) (Figura 5), feito por Anne Brigman em 1906, e o autorretrato Naturalmente Humana (Figura 6), feito pela artista catarinense Lilian Barbon, em 2012.

Em Soul of the Blasted Pine (Figura 5), a figura feminina se contorce para fora daquilo que sobrou de uma árvore, como se ali morasse ou como se daquilo fosse parte, seu próprio tronco se mescla ao tronco de madeira, ao qual seu corpo dá continuidade. Como o galho seco de uma árvore morta, seu braço e sua mão esquerda apontam para o céu, parecendo tentar alcançá-lo, como uma alma que se desprende do corpo e busca por redenção, luz, um novo caminho; abandonando a terra e a materialidade.

O céu tempestuoso se prepara para recebê-la, tudo indica que sua passagem será turbulenta e caótica. A inclinação da terra no enquadramento da fotografia passa 
a sensação de instabilidade; é difícil dizer se sobe ou se desce, se esta alma conseguirá ascender ou se será consumida pela terra.

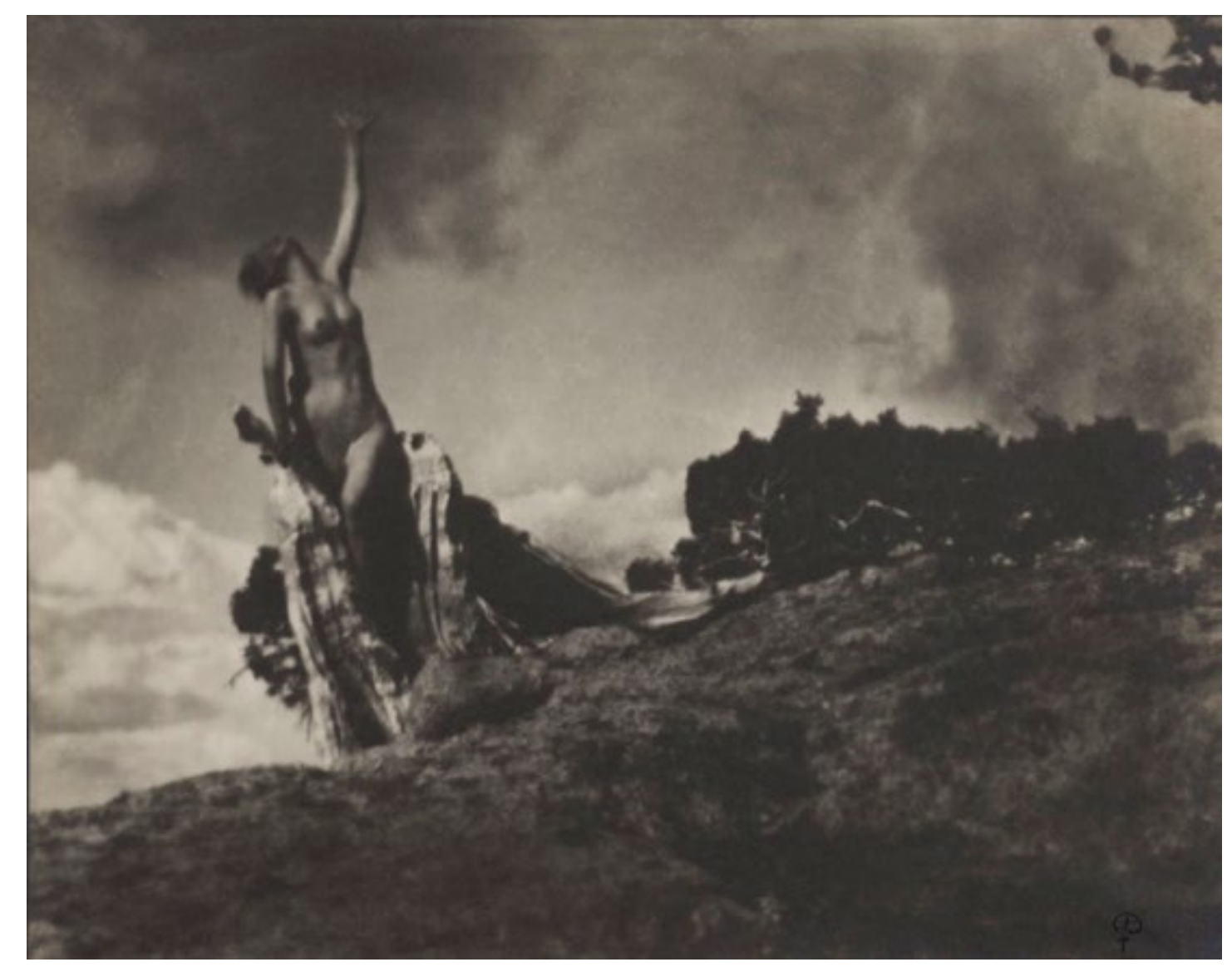

Fig. 5. Soul of the Blasted Pine (Alma do Pinheiro Maldito), Anne Brigman, 1906. Fotografia. Fonte: https://www.artsy.net/article/artsy-editorial-anne-brigman-pioneering-photographer-nude-self-

portraits

São muitas as interpretações possíveis para Naturalmente Humana (Figura 6). A posição de seu corpo lembra um feto em desenvolvimento, com a pele vascularizada, no entanto, parece ser nutrida pela escuridão que a cerca e engole, como o tempo e seu misterioso caminhar. Simultaneamente, as linhas espalhadas por seu corpo lembram rachaduras sobre a terra seca ou rachaduras em uma construção antiga que aos poucos se torna ruína, voltando ao pó. Se parecem ainda com pequenos labirintos e em seus lados mais obscuros é fácil se perder - a vida também tem seus labirintos - ou com a vista aérea dos rios mitológicos que dividem o mundo dos vivos e dos mortos.

Sua postura encolhida também pode indicar sofrimento e evidencia a fragilidade de quem sente o corpo ruindo e, naturalmente humana, sabe que essa casca não durará para sempre, há de se partir. As mãos tentam proteger, acalentar, minimizar os danos. O rosto está perdido nas sombras e enterra consigo a identidade e individualidade, reforçando a questão humana e plural, é fácil colocar-se em seu lugar, preencher a lacuna com um rosto querido ou mesmo com o próprio rosto. 
A questão do retrato começa talvez no dia em que, diante de nosso olhar aterrado, um rosto amado, um rosto próximo cai contra o solo para não se levantar mais. Para finalmente desaparecer na terra e se misturar a ela. A questão do retrato começa talvez no dia em que um rosto começa diante de mim a não estar mais aí porque a terra começa a devorá-lo. (ARTSTUDIO N²1, 1991)

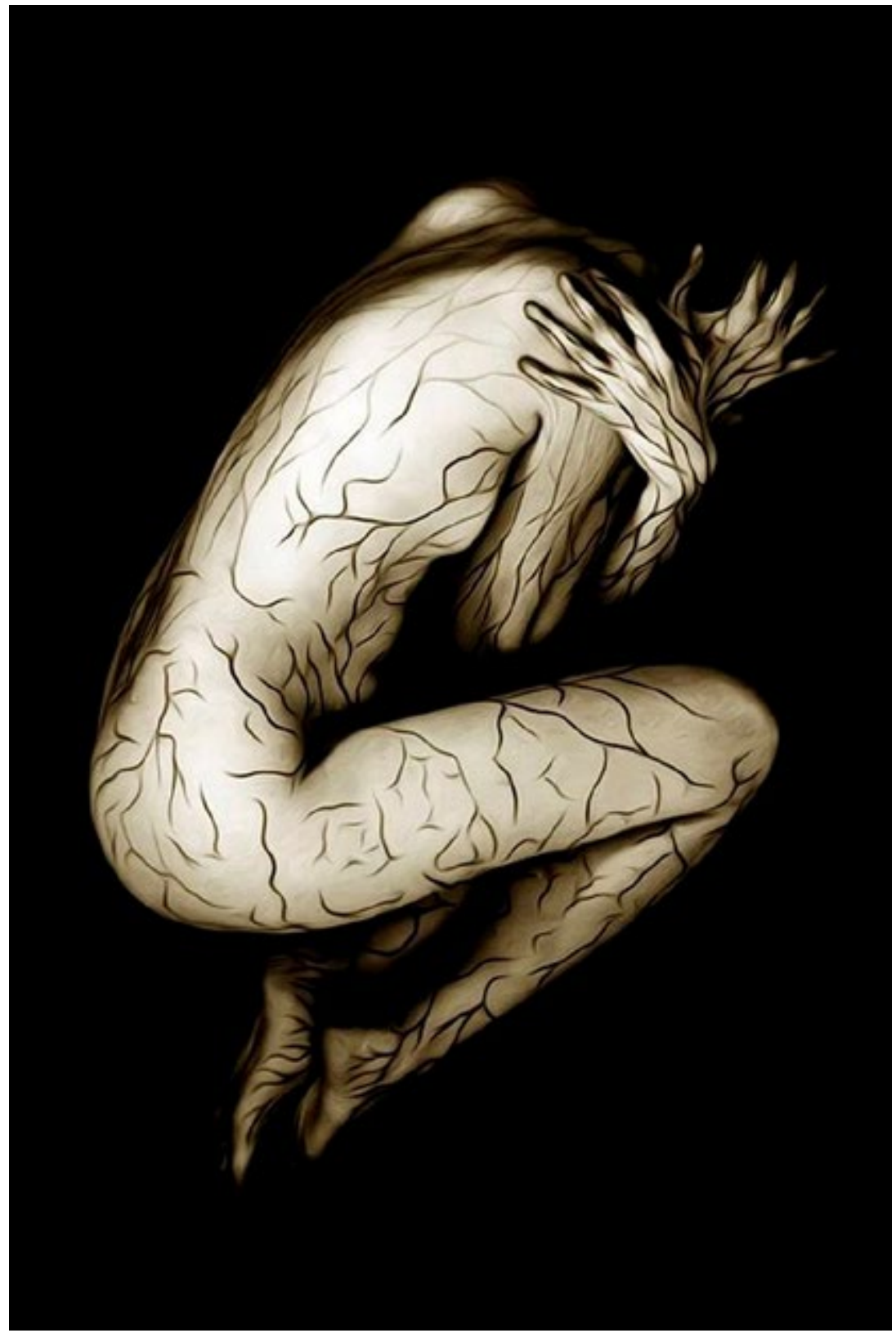

Fig. 6. Naturalmente Humana, Lilian Barbon, 2012. Fotografia. Fonte: https://lilianbarbon.wixsite. com/fotografias/autoral

Entre as obras citadas, a mais antiga é de John Everett Millais (Figura 1), que em 1858 pintou fortes personagens femininas, com sua visão moderna, em desacordo com a época em que viveu. As demais obras (Figuras 2, 3, 4, 5 e 6), no entanto, foram feitas e protagonizadas por mulheres, que com o tempo passaram a ter espaço e autonomia para falar de si mesmas através da arte. 
À medida em que estas obras são relacionadas, elas são também ressignificadas e, assim, sobrevivem. Para Didi-Huberman(2006), a imagem é constituída por tempos heterogêneos e descontínuos e o olhar contemporâneo pode conectá-los e trazer consigo novos significados. As grandes questões humanas, como o tempo, a morte, o desaparecimento e a natureza, são o que sobrevivem nas imagens apresentadas. Nelas, é possível identificar a Nachleben cunhada por Warburg (2010), ou vida póstuma da Antiguidade, que permanece como assombração em épocas posteriores. É a reaparição de algo que estava aparentemente morto no passado, mas que na verdade estava apenas guardado na memória e é ativado em determinadas circunstâncias. Os tempos se mesclam e os pontos de partida e chegada se deslocam constantemente, misturando-se.

As obras de John Everett Millais (Figura 1), Danny Bittencourt (Figura 2), Sarah Uriarte (Figura 3), Francesca Woodman (Figura 4), Lilian Barbon (Figura 5) e Anne Brigman (Figura 6) apresentam um mistério, algo que está enterrado e que desperta em mim especial curiosidade. As imagens parecem brincar com quem as observa, ocultando ou revelando partes de si, que contêm significados difíceis de apreender, quando se pensa estar alcançando-os eles se escondem de novo.

A obra de arte parece pertencer ao mesmo tempo e de forma enigmática, à realidade e à possibilidade, ou seja, ao que é e àquilo que pode ser. Esse é o seu poder. E é esse poder que nos interessa. O poder do enigma que nos mostra que aquilo que é lido de uma forma, pode também ser lido de outra, o que coloca o leitor em uma posição de absoluta solidão e responsabilidade diante da escolha que faz naquele momento, pois sabe que não há uma certeza, um chão sólido onde colocar seus pés, um fundamento, há apenas o risco de uma aventura. (...) Se lidamos com imagens, estamos lidando com imaginário também. (MAKOWIECKY; CHEREM, 2016)

Analisar uma imagem do passado é, para Didi-Huberman (2012), como caminhar entre ruínas. Algo sobrevive em meio ao que foi destruído e para enxergar é necessária a habilidade de comparar aquilo que sobreviveu àquilo que já desapareceu. Colocar em diálogo imagens de diferentes artistas, de localidades e tempos distintos exige isso.

\section{Referências}

AGAMBEN, Giorgio. Ninfas. S.P.: Hedra, 2012.

ARTSTUDIO N²1: Le Portrait Contemporain. Paris: Artstudio, 1991.

BITTENCOURT, Danny. Fotografia Híbrida. Porto Alegre: Independente, 2018.

COLI, Jorge. O corpo da liberdade: reflexões sobre a pintura do século XIX. São Paulo: Cosac \& Naify, $2010^{a}$, p.14 
COLI, Jorge. Reflexões sobre a ideia de semelhança, de artista e de autor nas artes - Exemplos do século XIX. 19\&20, Rio de Janeiro, v. V, n. 3, jul. 2010. Disponível em: <http://www. dezenovevinte.net/ha/coli.htm>.

DIDI-HUBERMAN, Georges. A imagem queima. Curitiba: ed. Medusa, 2018.

DIDI-HUBERMAN, Georges. Ante el tiempo. Argentina: Adriana Hidalgo, 2006.

DIDI-HUBERMAN, Georges. Imagens apesar de tudo. Lisboa: KKYM, 2012.

FOWLE, Frances. Sir John Everett Millais, Bt The Vale of Rest 1858-9. 2000. Disponível em: <https://www.tate.org.uk/art/artworks/millais-the-vale-of-rest-n01507>. Acesso em: 25 jul. 2019.

MAKOWIECKY, Sandra; CHEREM, Rosângela. Pensatas sobre arte e tempo, imagem e arquivo. Florianópolis: Aaesc, 2016.

WARBURG, Aby. Histórias de Fantasma Para Gente Grande. São Paulo: Editora Schwarcz S.a., 2010. 